\title{
CUSTOMISED INSTITUTIONAL EXPERIENCES' USE IN CURBING UNWANTED OCCUPATIONAL INCIDENTS AND ACCIDENTS
}

\author{
UDC $331.45 \% .46$
}

\section{Felistas R. Zimano}

\author{
Midlands State University, Gweru, Zimbabwe
}

\begin{abstract}
This paper illustrates the helpfulness of collecting intelligence from organisations' occupational incidents into an inventory for use, proactively, to curb unwanted occupational incidents. Among other things, ethical illusions are brought out as pertinent underlying drivers of unconstructive occupational incidents. This documentation presents qualitative findings from mini-focus-group interactions with a collective of Occupational Health and Safety (OHS) officers from nine Zimbabwean organisations. The OHS officers' accounts substantiate the prevalence of recurrent unwanted incidents which can be attributed to ethical illusions pitfall. As a mitigation measure, the researchers propose and rationalise harnessing customised institutional experience. This information can then be developed and shared through conventional or virtual sharing platforms. Accordingly, it becomes imperative for employees and OHS officers to volunteer and gather knowledge, respectively, whenever ethical transgressions, unwanted occupational incidents, and occupational accidents occur. This can help organisations to build learning material for all to avoid recurrence of similar pitfalls.
\end{abstract}

Key words: Ethical illusions, occupational incidents, record-keeping, organisational culture, institutional experience, Occupational Health and Safety (OHS)

\section{INTRODUCTION}

The occurrence of occupational incidents may positively or negatively affect individuals, organisations and national economies. Negative occupational incidents are responsible for the bulk of time and productivity losses to individuals and organisations [12]. Occupational accidents are always negative save for the fact that they can provide a learning platform for the future. As such, there is a need and calls for the development of effective strategies towards curbing the negative effects [24]. It becomes crucial for

Received May 10, 2019 / Accepted July 7, 2019

Corresponding author: Felistas R. Zimano

Midlands State University, Zimbabwe, P Bag 9055. Gweru, Zimbabwe

E-mail: zimanof941@gmail.com 
employers and employees, as immediate stakeholders, to invest time and energy towards finding ways to curtail or eliminate the occurrence of errors and accidents. Losses that happen due to unwanted occupational incidents and accidents are wide-ranging. They may include time losses, capital assets losses, physical condition losses and even loss of lives. The underlying causes of these incidences and accidents can be traced to a lot of things. This may include faulty equipment, poor working conditions, and human miscalculations. (Un)ethical choices crop up from an interplay between personal traits of the one making decisions and the features of the situation at hand [20]. Of particular interest to this research is the human error component in the incidents and accidents equation. This, unfortunately, remains under-examined by researchers [24]. On the other hand, the numbers of fatalities from occupational accidents continue to increase [10]. Human error is a product of multifarious interconnected factors. In light of this, human error occurs because of the interplay between faulty decisions occurring due to, among other things: ethical fading, dangerous rewards systems, motivated blindness, and ethical illusions. Age and work experience also contribute to human-related factors. Individual or organisational historic events along with diversity variables in the population (like age and culture) may compel (un)ethical decisions [25]. Understanding matters of group dynamics, as the paper will show, are also of importance in understanding and solving ethical problems towards curbing negative occupational incidents and accidents. For example, research shows that merely having a joint commitment in a group of people is not enough to account for shared intention as established [13]. Such knowledge, inter alia, should be known so that people avoid assumptions when dealing with groups.

Accordingly, by studying a convenient sample of Zimbabwean OHS officers' occupational incidents' accounts and a review of literature, this paper exposes the learning gap in measures to hold back occupational incidences and accidents as shown by their recurrent nature. The paper also illuminates the place of ethical illusions in occupational incidents, accidents and errors. This phenomenon will be defined and explained in the ensuing sections. As a way of recommendations, the paper proposes measures that organisations can put in place in order to trim down and do away with negative occupational incidences by reducing the ethical illusions pitfall. The measure proposed herein works proactively - by means of the harnessing customised organisational incidences and errors' intelligence. Such intelligence, as will be expounded, can become the virtual awareness teaching and learning hub for that particular organisation and others with similar processes and procedures. This is consistent with recommendations on the need for demarcations to be made such that actions might be interrogated on whether they constitute means to an end or probability raisers in the occurrence of ethical errors [3]. There is also wisdom that organisations must not depend on employees' and managers' moral intuition but they should instead find ways and invest in creating a culture of ethical behaviour through performance management systems [21]. Once an ethical system is established crucial aspects of organisational citizenship behaviour also improve. These are job satisfaction and commitment to the organisation which grew due to the prevailing ethical climate's ability to nurture these desired traits. 


\section{NATURE AND CONTEXT OF OCCUPATIONAL INCIDENTS AND ACCIDENTS}

Occupational incidents refer to all activities, positive or negative, that occur in the workplace during the carrying out of contractual obligations [3]. On the other hand, occupational accidents are those work-related injuries as a result of unexpected and unplanned events that can culminate in occupational injuries: the physical damages on a person [12]. These accidents do not occur naturally but are a result of unsafe acts, unsafe working conditions or a combination of both. To date, occupational accidents and unwanted occupational incidents remain a weigh down in economic and social terms [2]. There is a need to bring together moral, legislative and business aspects in formulating occupational incidents management measures [2]. In this vein, it can be argued that the burdensome nature of these unwanted occupational incidents and accidents make it worthwhile to be proactive by crafting policies that are meant to contain, take the edge off and turn off unwanted occupational incidents and accidents.

\subsection{Intelligence on ethical pitfalls' drivers from literature}

In order to effectively account for the research findings, conclusions and probable recommendations, this section brings out insights from the literature on factors informing actions. Foremost, it is crucial to appreciate that employees, as individuals, have various reasons for actions that they make at work. The reasons assumed by employees propel the means they adopt in fulfilling a certain task [3]. Moreover, when working as groups there are chances that individuals take actions based on assumptions. However, having a shared intention does not necessarily culminate in joint commitment [13]. The inverse is also true, a shared commitment must not be taken to mean shared intention [13]. In this instance, as people work in a team, the levels of commitment and intentions may vary. This is why some philosophers opine that interests and wrongs have a connection [11]. As such, it is prudent to anticipate varying levels of commitment even with shared intention and vice versa [13].

Nevertheless, the possibility of joint commitments cannot be ruled out. This is where investigations need to be made to establish whether or not the group is in disjunction. Disjunction is a scenario in which joint commitment exits in the group but none of the members will be having the intention to act [13]. This situation means the desire will be there in thoughts but the desire is not being translated into action as no one in the group intends to act. There are several reasons to account for disjunctions in literature. Some scholars have pointed to the influence of drugs as a cause for concern. Intoxication can culminate in improper or even criminal acts [1]. Such acts under the influence of drugs, with some possibility, account for disjunctions. Intoxication also brings moral responsibility challenges [1].

When one makes decisions under the influence of drugs wrong omissions or commissions can happen. However, these omissions or commissions are not necessarily in the wrong. An act of refraining from doing something can be a desirable way out in occupational incidents [3]. In that case, refraining will be working as a positive and means for the good. This concept of omission or commission can also be understood in the context of resolutions that people make. In common cases, people make resolutions at the beginning of the year or careers among other situations signifying new beginnings. The beginning of a year can be marked in terms of the financial year in organisations, calendar 
year in life, or academic year for students Resolutions come as intentions. Resolutions have an ability to rein in judgement shift [16]. There are several reasons to account for judgement shift. Judgement shift can happen due to temptations as they have a tendency of pushing an individual into doing things in the wrong [16]. Temptations come as external forces that can compel people to do things that they, ordinarily, would not do [9]. This usually happens because of a potential reward that appeals to someone. This can be in the form of financial gains, psychological gains, and gains in more time to rest, promotion possibilities and several other gains prospects.

In making decisions, there is also the role played by testimonies. Moral testimonies allow individuals to gain a moral understanding of others [22]. By getting insights into other people's experiences, the listeners get a second-hand understanding of the ethical values underlying certain acts. However, there are requisites for one who can give moral testimonies and for one who can be given them. In this scenario, it can be argued that both the recipients and givers (advisors) of the moral testimonies are expected to satisfy some essentials, fundamentals and prerequisites for them to participate in these processes. One needs to have sound moral capacity understanding to become a good moral advisor [22]. On the part of the recipient, there is need for the ability to be able to recognise reliable moral advisors from the many advisors available [22]. If one cannot distinguish between a good and moral advisor then challenges are likely to happen. There are a lot of people who might want to give testimonies but not all qualify for the task. In order to correctly identify a sound moral advisor, there is need for extra evidence on top of moral testimonies that individuals give [22]. Also, checking one's competence is not enough as a measure for judging one's ability to give advice. It is possible that, for several reasons, a competent person may not be a good advisor [22]. This is because not all people are gifted in properly packaging advice for verbal delivery even though their actions will be reflecting that they have sound moral grounding.

It is possible that the desires one has and his/ her judgement can be in conflict [9]. This accounts for akratic actions. Such a phenomenon is when one's actions come out contrary to one's better judgement and commitment [23;8]. In this case the weak point is one's will. This weakness will lead someone to act in ways inconsistent to own moral values. A person's desires and judgement levels may be found conflicting such that the outcome becomes actions not consistent with one's commitment [9]. In such cases even the individual might be surprised about the outcome of their action as they will be anticipating better results. In essence, one's miscalculated judgement will have interfered with one's desires which culminate in actions inconsistent with one's desires.

In addition, globalisation also has an input in the ethical pitfalls dilemma debate. Globalisation has brought several dynamics that can compel the occurrence of ethical pitfalls. Globalisation has also led to employees' diversity in terms of age composition, groups' multiculturalism, values' diffusion and beliefs diversity among other things [4]. This can culminate in ethical illusions in that several factors come in as influencing how one makes judgements of own abilities.

With this knowledge in mind, the researchers appreciate that there are several causes of unwanted incidences and occupational accidents. The literature substantiates the fact that indeed there exist several factors driving the ethical pitfalls. As such, the forthcoming section details the methodology adopted herein in the quest to make contributions from research that can help curtail the recurrence of unwanted incidences and occupational accidents. 


\section{RESEARCH METHODOLOGY}

The Zimbabwe Lime and Cement group of companies hold periodic safety and health meetings. Organisations that belong to this collective include those that produce cement, fertilisers, building plaster materials among others like LaFarge cement, Sino cement and Earth-n-fire. The lead researcher had the opportunity to attend one such meeting as a guest. From sideshow interactions, the researcher established that individually, the OHS officers were apprehensive about negative occupational incidences happening in their organisations. This exposed a knowledge gap that warranted this research as there was evidently need to account for the incidences and find possible solutions. This is consistent with some conclusions buttressing the need for new methods to be found for teaching the identification and resolution of ethical issues and consequences [4]. It is from those insights that the lead researcher, in consultation with co-researchers, saw it worthwhile to embark on investigations to fill this research gap. That culminated in this paper.

With the permission of the organising authorities, the researchers did set up three minifocus group discussions (FGDs). There were three participants in each of the three miniFGDs to give a total of nine participants. The population was nine and the researchers used a census recruitment method as they included all the OHS officers in the study sample. The census method is when all elements of the population are included in the study [15]. The size of FGDs is usually informed, inter alia, by the type of participants [19]. In this case the researchers deemed mini-FGDs as best for the task since the participants held specialised occupational safety and health knowledge. In fact, all qualify as experts and these miniFGDs became expert panel ones. Expert panels are able to provide information based on evidence to guide research [7].

The mini-FGDs were all held one day one after the other. The researchers attended all the sessions to listen and capture deliberations. Audio recordings were utilised. Provisionally, each mini-FGD had two hours for open-ended deliberations on occupational incidences in their organisations. However, some did not exhaust the two hours as there was apparent theoretical saturation that warranted early winding off. Data are considered saturated when the new information does not bring in additional new elements such that it becomes of no use and do not change the understanding established thus far on the research experience [18].

\subsection{Mini-FGDS emerging themes}

Equipped with the mini-FGDs audio recordings, the researchers extracted organisational incidences accounts culminating into a number of themes being established through thematic analysis. Thematic analysis is a process which entails identification of themes and patterns in qualitative data [6]. The researchers followed the Braun and [6]'s six step framework as recommended by [17] The six step framework is a follows: Step 1-Becoming familiar with the data; Step 2-Generation of initial codes; Step 3- Search for themes; Step 4- Themes review; Step 5- Themes definition and Step 6- Writing up.

The themes that emerged for the mini FGDs were as follows:

- High recurrence of similar occupational incidence.

- Errors inconsistent with employees' background

- Employees surprised by own mistakes.

- Errors attributed to poor judgement. 


\subsection{Study findings}

The findings point to an underlying problem inherent in the respondents' organisations. The emerging themes summarise the obtaining situations in which employees are recurrently being involved in unethical behaviour that culminate in a number of unwanted occupational incidents and accidents. This is consistent with notes on unethical behaviour in organisations indicating that this is behaviour in which employees disregard the codes of moral expectations [21]. This means the code of ethics setting out the standards that one must adhere to may be available and clear but, for some reasons, employees fall into the pitfall of acting contrary to those dictates. The fact that there is a high recurrence of similar unwanted occupational incidents and accidents is cause for concern. This might be an indication pointing to the absence of a learning platform. The mere presence of regulations will not suffice to curb challenges if the regulations remain on paper of be the preserve of the management. Learning platforms can better alert others of ethical pitfalls encountered by their colleagues. Such platforms can be made available even through testimonies from fellow employees [22]. The institution of testimonies, as exposed in earlier sections, helps employees to learn from and teach each other although not all will be able to give testimonies due to individuals' capability deficiencies.

The fact that employees are reported as being surprised by their mistakes point to some underlying illusions in making decisions in which employees would be making errors in judging their abilities. That is the reason they get astonished on how they could get something wrong. They are, as it were, embarking on an activity confident that they will deliver but inadvertently find themselves in error. This is in line with earlier findings which indicated that a person's desires and judgement levels may be found conflicting such that the outcome becomes actions not consistent with one's commitment [9]. As such, it becomes of the essence of the organisation to put measures to ensure such judgements-related errors are minimised and possibly eliminated. More worrisomely, is the information that the errors keep occurring. This might point to the problems of the leadership as established by the connotations they derive from adjectives accompanying their titles [14]. In this case it means the unethical behaviour is being repeated due to weaknesses of the leadership. Although not covered in this paper, such issues also need to be taken into account as highlighted in the referred research. This is one thing that needs to be attended from various angles. Whilst those in engineering would want to make investigations on the machines and other factors in the work environment, it is prudent for the OHS managers to take measures to deal with the human component of the error.

In terms of research methodology, the methodology followed for this research seems to be very convenient. The researchers see the recruiting of experts at one point as a viable way of extracting data rather than having to engage each expert in his/her organisation. Holding mini-FGDs do not only serve the purpose of the research but it also allows peer teaching and learning for the experts as they share their organisations' experiences. However, there was evident early theoretical saturation which can be a downside. Although saturation may indicate that all the possible data has been extracted, it can also point to a high incidence of homogeneity in the population. Homogenous populations are those in which the elements or participants are too similar [26]. Such a scenario may culminate in findings with deficiencies. 


\section{RECOMMENDATIONS}

The intelligence established thus far from literature and FGDs investigations gives an array of advice to OHS practitioners, policymakers and scholars. Foremost, there is need to understand the various reasons that propel one into making an action. This can only be arrived at through continuous interactions with workers before they embark on a task checking their reasons for the methods they would want to adopt in completing a given task. When employees are working in groups, there is also need to understand that they remain individuals in a group [13]. This is so because their various assumptions and intentions may vary due to their underlying individual competences, desires and aspirations. As such, having workers in a shared commitment does not necessarily point to shared intentions. There is also need to understand the phenomenon of akratic actions in which actions that one produce are contrary to one's judgements $[23 ; 9 ; 8]$. The understanding of akratic actions can point to the need to understand the existence of ethical illusions and the need to curb them in order to arrest the recurrence of some occupational incidences.

The issue and effects of drugs also need to be understood by OHS. Both prescription and non-prescription drugs have side-effects that may impair one's judgements. These may pit someone to making unethical decisions. On the other hand, intoxication can lead to criminal acts and need to be checked [1]. Then there is the issue of testimonies. The wisdom in literature shows that testimonies can help people to get insights into what their colleagues have gone through [22]. Testimonies may appear in situations in which unethical decisions were made, as well as for situations in which ethical decisions were made. However, not all people can be good in giving moral advice of this nature. This brings in the need to gather more evidence to complement moral testimonies. In contemporary work environments, it is also prudent to appreciate and understand the impact of globalisation. Literature has it that globalisation has led to a lot of factors like cultural diversity and new ways of doing business that may increase the likelihood of ethical illusions [4].

Having established that, this paper proposes and recommends that there is a need to harness and utilize customised institutional intelligence for use in curbing recurring occupational incidences caused by ethical illusions pitfalls. By collecting reports on occupational incidents, accidents and employee accounts, OHS officers can build a database from which trend analysis can be made. Through encouraging the employees to share their experiences' knowledge with others, an organisation can curb recurrence of similar negative occupational incidents. As such, there is need to educate the employees to volunteer information when they make unethical decisions. From time to time there is also need to gather information from employees for those positive incidences in which ethical decisions would have been made. This will help in giving the learning alternatives. To embrace the modern way of doing things, such information can then be shared through virtual platforms in which employees have access as group members. Such platforms will help to unpack unethical behaviour and decisions before they recur. Such an initiative may go a long way in curbing recurring negative occupational incidents within organisations. This can also be used towards improving organisation's code of ethics as advised in literature [5]. This approach will fit in the proactive occupational health and safety management frameworks as called for by some scholars [2]. It is never wise to procrastinate and react after an incident, rather, teach about occupational incidents and nip the negative ones in the bud. 
On methodology, the researchers appreciate the worrisomely early theoretical saturation that occurred. This, as indicated in the findings, may be pointing to homogeneity in the respondent selected as they are all experts in one line of OHS. In order to get more views on this phenomenon, there is need to expand and redefine the population and probably include the employees who hold no expert knowledge. Such an approach may broaden the knowledge of recurring accidents in workplaces. More information may expose other knowledge that OHS experts are blind to.

\section{CONCLUSION}

The narratives from the OHS managers in this study point to a missing solution. This means there is something missing in the generic ethical pitfalls solutions. Literature is awash with solutions from accepted ethical theories that one can use as a starting point. The accepted ethical theories are those mainline ethical theories dominating core components of most ethics texts or courses [4]. This paper has established and proposed the need for a more practical and customised solution. The continued occurrence of unconstructive occupational incidents signifies the need to embrace existing solutions as well as devise better ones. The proposed method herein is for OHS officers to continuously gather intelligence on (un)ethical decisions from employees. There is also need to create virtual platforms through which employees learn and teach each other through shared testimonies such that information does not get privatised whilst organisations continue to experience similar unhelpful occupational incidents time and again. The findings so far point to a scenario in which events are being evaluated and examined but the intelligence established is not passed on to the rest of the employees in order to improve their approaches and curtail recurrent ethical pitfalls. Such information, if kept from the employees become information in vain as it merely enriches records without adding value to the stakeholders in the organisation.

\section{REFERENCES}

1. Agule, C. K., (2016), Resisting tracing's siren song, Journal of Ethics and Social Philosophy. Vol. 10, No. 1, pp. 1-24. DOI https://doi.org/10.26556/jesp.v10i1.94

2. Battaglia, M., Frey, M., and Passetti, E., (2014), Accidents at Work and Costs Analysis: A Field Study in a Large Italian Company, Industrial Health. Vol. 52, pp. 354-366. DOI: 10.2486/indhealth.2013-0168

3. Bedke, M. S., (2017), Ends to means: A probability raising account of means and the weight of reasons to take them, Journal of Ethics and Social Philosophy. Vol. X11, No. 1, pp. 6-28. DOI: https://doi.org/ 10.26556/jesp.v12i1.207

4. Bowden, P., (2015), Ethics across Organisational Spectrum, Research in Ethical Issues in Organisations, Vol 14, pp. 93-119.

5. Caserio, C. and Napoli, F., (2017), Value relevance and code of ethics: An empirical analysis of Italian listed Companies, International Journal of Business Governance and Ethics. Vol. 12, No. 1, pp. 1-20. https://doi.org/10.1504/IJBGE.2017.085238

6. Clarke, V and Braun, V., (2013), Teaching Thematic Analysis: Overcoming Challenges and Developing Strategies for Effective Learning, The Psychologist. Vol. 26, No. 2, pp. 120-123.

7. Coutler, I., Elfenbaum, O., Jain, S., and Jonas, W., (2016), SEaRCH ${ }^{\mathrm{TM}}$ expert panel process: streamlining the link between evidence and practice, BMC Research Notes. Vol. 9, No. 16.

8. Fiecconi, E. C., (2018), Aristotle on the structure of Akratic Action, Phronesis. Vol. 63, No. 3, pp. 229256. DOI:https://doi.org/10.1163/15685284-12341350

9. Fossey, P., (2015), Illusions of Value, Journal of Ethics and Social Philosophy, pp. 1-6. DOI https://doi.org/ 10.26556/jesp.v9i2.174 
10. Hämäläinen, P., Takala, J and Kiat, T. B., (2017), Global Estimates of Occupational Accidents and Work-related Illnesses, WSH Institute Publications. Singapore.

11. Healey, R., (2017), Interests, wrongs and injury hypothesis, Journal of Ethics and Social Philosophy. Vol. X11, No. 1, pp. 6-28. DOI https://doi.org/10.26556/jesp.v12i1.215

12. Jovanović, J., Arandelović, M., and Jovanović, M., (2004), Multidisciplinary Aspects of Occupational Accidents and Injuries, Working and Living Environmental Protection. Vol. 2, No. 4, pp. 325-333.

13. Kopec, M., and Miller, S., (2018), Shared Intention is not Joint Commitment, Journal of Ethics and Social Philosophy. Vol. X111, No. 2, pp. 179-189. DOI https://doi.org/10.26556/jesp.v13i2.250

14. Lašáková, A and Remišová, A., (2015), Unethical leadership: Current Theoretical Trends and Conceptualisation, Procedia Economics and Finance. Vol. 34, pp. 319-328. https://doi.org/10.1016/S2212-5671(15)01636-6

15. Lavrakas, P. J., (2008), Encyclopedia of survey research methods, Thousand Oaks, CA: Sage Publications

16. Liberman, A., (2016), Reconsidering resolutions, Journal of Ethics and Social Philosophy. Vol. 10, No 2, pp. 1-26. DOI https://doi.org/10.26556/jesp.v10i2.98

17. Maguire, M and Delahunt, B., (2017), Doing a Thematic Analysis: A Practical, step-by-step guide for Learning and Teaching scholars, AISHE-J. Vol. 9, No. 3, pp. 3351-3365.

18. Nascimento, L. C. N., Souza, T. V., Oliviera, I. C. S., Moraes, J. R. M. M., Aguiar, R. C. B., and Silva, L. F., (2018), Theoretical Saturation in Qualitative Research: An Experience Report in Interview with School Children, Rev Bras Enferm. Vol. 71, No. 1, pp. 228-233. http://dx.doi.org/10.1590/0034-7167-2016-0616

19. Onwuegbuzie, A. J., Dickinson, W. B., Leech, N. L., and Zoran, A. G., (2009), A Qualitative Framework for Collecting and Analyzing Data in Focus Group Research, International Journal of Qualitative Methods, Vol. 8, No. 3, pp. 1-21. https://doi.org/10.1177/160940690900800301

20. Palazzo, G., Krings, F., and Hoffrage, U., (2012), Ethical Blindness, Journal of Business Ethics. Vol. 109, pp. 323-338. http://dx.doi.org/10.2139/ssrn.2212617

21. Singh, P and Twalo, T. G., (2015), Mismanaging Unethical Behaviour in the Workplace, Journal of Applied Business Research. Vol. 31, No. 2, pp. 515-530.

22. Sliwa, P., (2017), Moral Understanding as Knowing Right from Wrong, Ethics., pp. 521-552

23. Stroud, S and Tappelet, C (eds.), (2003), Weakness of Will and Practical Irrationality, Oxford University Press: Oxford.

24. Umeokafor, N. I., Evaggelinos, K., Lundy, S., Isaac, D., Allan, S., Igwegbe, O., Umeokafor, K and Umeadi, B. B. N., (2014), The pattern of Occupational Accidents, Injuries, Accident Causal Factors and Intervention in Nigerian Factories, Developing Country Studies, Vol. 4, No. 15, pp. 119-129.

25. van der Walt, F., Jonck, P., and Soyabeni, N. C., (2016), Work Ethics of Different Generational Cohorts in South Africa, African Journal of Business Ethics. Vol. 10, No 1, pp. 52-66. DOI: https://doi.org/10. $15249 / 10-1-101$

26. $* * * * * * * .,(2017)$, (By this author)

\section{INDIVIDUALNA ISKUSTVA ORGANIZACIJA U ZAŠTITI OD NEŽELJENIH DOGAĐAJA I AKCIDENATA NA RADU}

U radu je prikazan značaj prikupljanja podataka o nezgodama na radu u organizacijama u cilju sprečavanja neželjenih događaja. Između ostalog, etičke zamke smatraju se jednim od veoma važnih pokretača nezgoda na radu. Dokumentaciju o nezgodama na radu, koja je tema ovog rada, čine rezultati kvalitativnih istraživanja nastalih kroz interakciju mini-fokus grupe i zaposlenih u službi za bezbednost $i$ zdravlje na radu (BZNR) iz devet organizacija u Zimbabveu. Zaposleni u službi BZNR potvrđuju rasprostranjenost ponavljajućih neželjenih događaja koji se mogu pripisati zamkama koje nastaju zbog etičkih iluzija. Kako bi se ublažili posledice, istraživači smatraju da je oslanjanje na iskustvo drugih organizacija od izuzetnog značaja. Takve informacije se mogu podeliti putem konvencionalnih ili virtualnih platformi za deljenje informacija. Takođe je neophodno da zaposleni u službi za bezbednost i zdravlje na radu dobrovoljno prikupljaju informacije o svim etičkim povredama rada, neželjenim događajima na radu i profesionalnim nezgodama. Ove informacije mogu biti od pomoći organizacijama da naprave materijal za učenje za svoje zaposlene kako bi se povećala produktivnost i sprečilo ponovno pojavljivanje sličnih zamki.

Ključne reči: etičke zamke, nezgode na radu, vođenje dokumentacije, organizaciona kultura, institucionalno iskustvo, bezbednost i zdravlje na radu (BZNR) 